\title{
Selection of parental lines among round fruited brinjal for hybridization aim- ing at export promotion
}

\author{
Varun Durwas Shende $^{1}$, Tania Seth ${ }^{2}$, Subhra Mukherjee ${ }^{1}$ and Arup Chattopadhyay ${ }^{3 *}$ \\ ${ }^{1}$ Department of Genetics and Plant Breeding, Faculty of Agriculture, Bidhan Chandra Krishi Viswavidyalaya, \\ Nadia-741252 (West Bengal), INDIA \\ ${ }^{2}$ ICAR-Indian Institute of Vegetable Research, Varanasi- 221305 (U.P.), INDIA \\ ${ }^{3}$ All India Coordinated Research Project on Vegetable Crops, Directorate of Research, Bidhan Chandra Krishi \\ Viswavidyalaya, Nadia741252 (West Bengal), INDIA \\ *Corresponding author. E-mail: chattopadhyay.arup@gmail.com
}

Received: July 12, 2016; Revised received: January 1, 2017; Accepted: February 14, 2017

\begin{abstract}
Selection of parental lines for considering export trade in hybridization programme is a new approach in brinjal breeding. Eight quantitative characters were taken to estimate genetic variation and relationships among twenty seven genotypes of round fruited brinjal, and to identify potential donors for the development of recombinants suitable for export. Analysis of variation revealed considerable level of variability among the genotypes. High broad sense heritability (>80\%) and genetic advance as per cent of mean (>20\%) were observed for the maximum number of traits under study. Among the yield components, only number of marketable fruits per plant showed positive and significant correlation $(r=0.771$ and 0.725 at genotypic and phenotypic level, respectively) with marketable fruit yield per plant. However, number of marketable fruits per plant (1.24) followed by average fruit weight (0.834) exhibited maximum positive direct effects on marketable fruit yield per plant suggesting to give emphasis on these traits while imposing selection for amenability in fruit yield of round fruited brinjal. Principal component analysis showed the amount of variation by principal components 1 to 4 viz., 26.75, 49.98, 69.81 and $84.28 \%$, respectively. Divergence analysis based on various yield component traits grouped 27 brinjal genotypes into nine main clusters. Dendrogram based on hierarchal clustering grouped genotypes based on their yield component traits rather than their geographic origin. Based on averages and principal component analysis, six genotypes (BCB-30, Deshi Makra, Gujrat Brinjal Round, 09/BRBWRes-3, BCB-10, 10/BRRVar-2) appeared to be promising donors for use in export oriented breeding programme.
\end{abstract}

Keywords: Brinjal, Clustering, Correlation, Diversity, Export, Principal component analysis

\section{INTRODUCTION}

Brinjal (Solanum melongena L.) can be grown in almost all parts of the world except in higher altitudes, and can act as major source of income particularly for the small and marginal farmers. The crop has large diversity for fruit color, shape, size and other morphological traits (Cericola et al., 2013) and large number of cultivars/hybrids have been cultivated throughout the world according to market needs and consumer demands (Sidhu et al., 2005, Chattopadhyay et al. ,2011). The crop is one the favorite export commodities in India mainly destined to Sri Lanka, Maldives, Singapore, Sudan and Mali (Vanitha et al., 2013). Round fruit shape with glossy purple colour having green calyx and devoid of spines in any parts of the plant are important export criteria specified by the Government of India (Singh and Pandey, 1993). Genotypes of brinjal involving mixture of fruit shapes have been characterized in the eastern Gangetic plains of India through different studies (Hazra et al., 2003,
Chattopadhyay et al., 2011). No varieties in eastern India could match the export specification as required in international market. Therefore, identification of round fruited brinjal for export purpose is the need of the hour from this zone. Hence, an attempt has been taken to evaluate and characterize the existing round fruited germplasm of brinjal and to identify potential line for obtaining the best recombinants for export purpose.

\section{MATERIALS AND METHODS}

Plant materials and field growing: Seeds of twenty seven advanced lines/varieties of brinjal collected from different sources of India were sown in well-prepared nursery bed and four weeks old seedlings were transplanted following Randomized Block Design with 3 replications at a spacing of $60 \mathrm{~cm}$ in both ways accommodating 30 plants in each plot during $3^{\text {rd }}$ week of July, 2014 at Research Farm of Bidhan Chandra Krishi Viswavidyalaya, Kalyani, Nadia, West Bengal, India. Normal package of practices were followed to raise the 
Varun Durwas Shende et al. / J. Appl. \& Nat. Sci. 9 (1): 451 - 455 (2017)

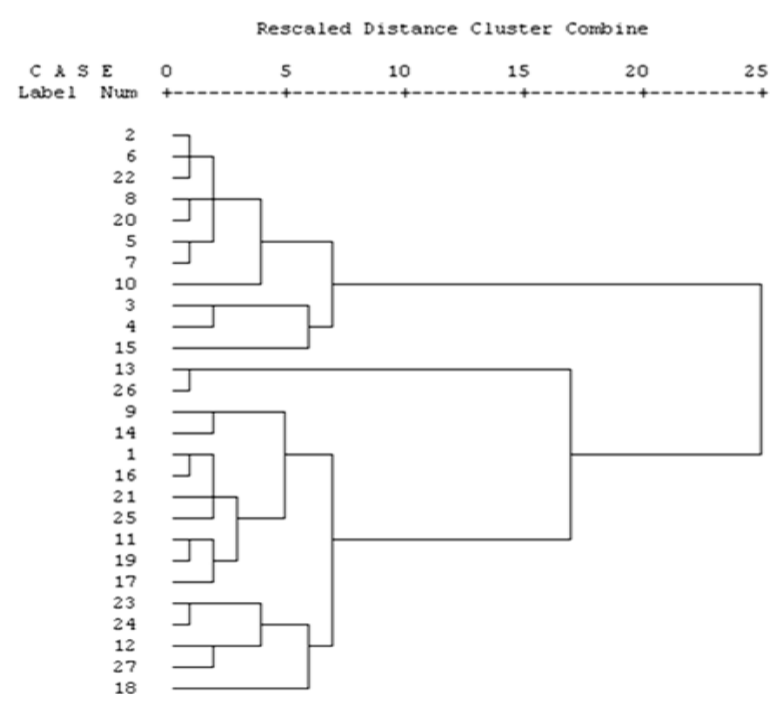

Fig. 1. Dendrogram based on cluster analysis for various yield component traits of brinjal genotypes.

Genotype 1:10/BRRVar-2, 2:10/BRRVar-3, 3:10/BRRVar-4, 4:10/BRR Var-5, 5:10/BRRVar-6, 6:10/BRRVar-7, 7:Swarna Mani, 8:KS-224, 9:Gujrat Brinjal Round, 10: Deshi Makra, 11: BCB-10, 12: IIVR Purple Round, 13: 09/BRBWRES-3, 14: Punjab Brinjal Round, 15: Gujrat SRP Round, 16: 12/ SPTBRVAR-1, 17: 12/SPTBRVAR-2,18: 12/SPTBRVAR-3, 19: 12/SPTBRVAR-4, 20: 12/SPTBRVAR-5, 21: 12/ SPTBRVAR-6, 22: 12/SPTBRVAR-7, 23: 12/SPTBRVAR-8, 24: 12/SPTBR VAR-9, 25: 12/SPTBRVAR-10, 26: 12/ BRBWRES-7, 27: $B C B-30$.

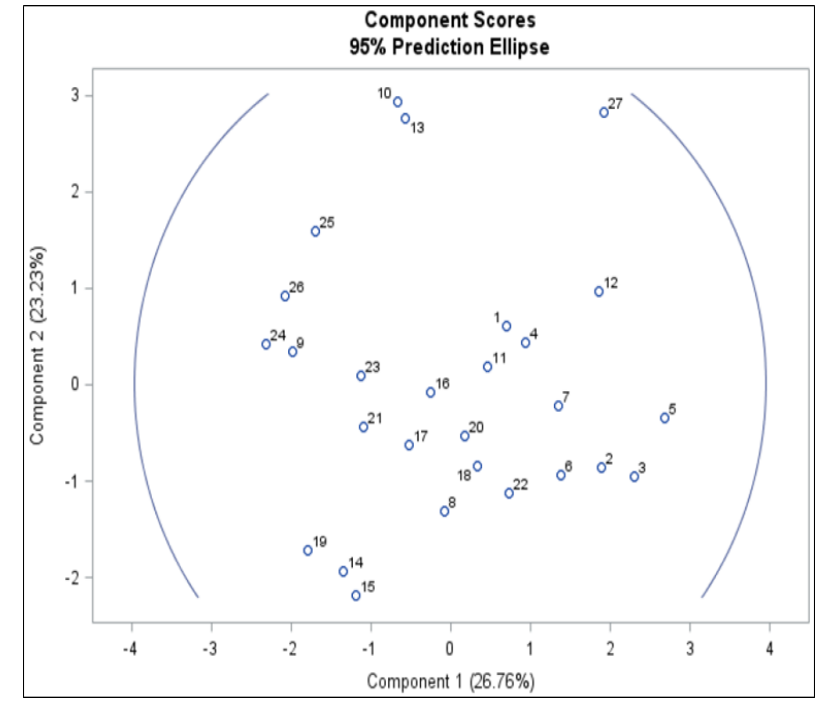

Fig. 2. Scattered diagram produced by PCA, Genotype 1:10/ BRRVar-2, 2:10/BRRVar-3, 3:10/BRRVar-4, 4:10/BRR Var5, 5:10/BRRVar-6, 6:10/BRRVar-7, 7:Swarna Mani, 8:KS224, 9:Gujrat Brinjal Round, 10: Deshi Makra, 11: BCB-10, 12: IIVR Purple Round, 13: 09/BRBWRES-3, 14: Punjab Brinjal Round, 15: Gujrat SRP Round, 16: 12/SPTBRVAR-1, 17: 12/SPTBRVAR-2,18: 12/SPTBRVAR-3, 19: 12/ SPTBRVAR-4, 20: 12/SPTBRVAR-5, 21: 12/SPTBRVAR-6, 22: 12/SPTBRVAR-7, 23: 12/SPTBRVAR-8, 24: 12/SPTBR VAR-9, 25: 12/SPTBRVAR-10, 26: 12/BRBWRES-7, 27: $B C B-30$.

Table 1. Mean, range and estimates of genetic parameters of twenty-seven genotypes of round fruited brinjal.

\begin{tabular}{|c|c|c|c|c|c|c|c|}
\hline Characters & Mean & Range & $\begin{array}{c}\text { GCV } \\
(\%)\end{array}$ & $\begin{array}{l}\text { PCV } \\
(\%)\end{array}$ & $\begin{array}{l}\text { GCV : } \\
\text { PCV }\end{array}$ & $\begin{array}{c}\text { Heritability } \\
(\%) \text { in broad } \\
\text { sense }\end{array}$ & $\begin{array}{c}\text { Genetic ad- } \\
\text { vance as }(\%) \\
\text { of mean }\end{array}$ \\
\hline Days to $1^{\text {st }}$ flowering & 49.35 & $43.67-63.67$ & 9.84 & 10.80 & 91.11 & 82.99 & 18.46 \\
\hline Days to $50 \%$ flowering & 63.08 & $49.67-76.33$ & 9.82 & 10.45 & 93.97 & 88.34 & 19.01 \\
\hline Plant height $(\mathrm{cm})$ & 92.00 & $74.33-116.17$ & 10.02 & 11.07 & 90.51 & 81.93 & 18.68 \\
\hline Fruit length $(\mathrm{cm})$ & 9.63 & $6.79-12.16$ & 13.46 & 13.52 & 99.56 & 99.05 & 27.59 \\
\hline Fruit girth $(\mathrm{cm})$ & 7.53 & $5.42-9.83$ & 14.46 & 14.60 & 99.04 & 98.18 & 29.52 \\
\hline Average fruit weight $(\mathrm{g})$ & 198.06 & $135.67-250.00$ & 14.71 & 15.27 & 96.33 & 92.79 & 29.18 \\
\hline $\begin{array}{l}\text { Number of marketable fruits/ } \\
\text { plant }\end{array}$ & 6.22 & $4.67-10.33$ & 27.07 & 28.63 & 94.55 & 89.40 & 52.72 \\
\hline Marketable fruit yield (kg/plant) & 1.20 & $0.83-2.43$ & 25.15 & 25.28 & 99.49 & 99.03 & 51.56 \\
\hline
\end{tabular}

Table 2. Genotypic and Phenotypic correlations and direct effects of seven characters at phenotypic level on marketable fruit yield/plant.

\begin{tabular}{lccc}
\hline Characters & rg with yield/plant & rp with yield/plant & Direct effect on yield/plant \\
\hline Days to 1st flowering & -0.033 & -0.036 & 0.054 \\
Days to 50\% flowering & -0.051 & -0.059 & 0.032 \\
Plant height (cm) & -0.062 & -0.065 & 0.113 \\
Fruit length (cm) & 0.004 & 0.002 & -0.061 \\
Fruit girth (cm) & 0.094 & 0.092 & -0.079 \\
Average fruit weight (g) & 0.159 & 0.143 & 0.834 \\
Number of marketable fruits/plant & $0.771^{* *}$ & $0.725^{* *}$ & 1.242 \\
\hline
\end{tabular}

**Significant at $\mathrm{P}<0.1 \%$ level of probability; $\mathrm{rg}=$ Genotypic correlation coefficient; $\mathrm{rp}=$ Phenotypic correlation coefficient; Residual effect $=0.052$ 
good crop (Chattopadhyay et al., 2007).

Observations recorded: Observations were recorded on days to first flowering, days to $50 \%$ flowering, plant height $(\mathrm{cm})$, fruit length $(\mathrm{cm})$, fruit girth $(\mathrm{cm})$, fruit weight $(\mathrm{g})$, number of marketable fruits per plant and marketable fruit yield per plant $(\mathrm{kg})$ from fifteen randomly selected plants from each plot. The marketable fruit yield per plant was calculated from the total fruit yield/plant excluding fruit borer damaged fruits from total fruit yield.

Statistical analysis: Mean values of genotypes were computed for determining analysis of variance. Heritability in broad sense and Genetic Advance (GA) were estimated using the method of Hanson et al. (1956). Correlation coefficients at genotypic and phenotypic levels were calculated as per Johnson et al. (1955). Path coefficient analysis as suggested by Dewey and $\mathrm{Lu}$ (1959) was used to partition the genotypic correlation into components of direct and indirect effects. $\mathrm{D}^{2}$ statistic (Mahalanobis, 1936) was used for assessing the genetic divergence of genotypes for eight quantitative traits mentioned above. The grouping of the populations was done by using Tocher's method as described by Rao (1952). Subsequently hierarchical cluster analysis has been done with those same genotypes in order to observe the degree of association according to their characteristics that was expressed in dendrogram following Ward's (1963) method. Statistical analyses were done using statistics analytical software SPSS Professional Version 13.0.

\section{RESULTS AND DISCUSSION}

Genetic variability and heritability: The variance analysis showed that genotypes differed significantly among themselves for all the characters under study. In general, the magnitude of phenotypic coefficient of variation $(\mathrm{PCV})$ was higher than genotypic coefficient of variation $(\mathrm{GCV})$ for all the characters under study indicating that the apparent variation was also due to the favorable influence of environment and selection based on these traits sometimes may be misleading (Table 1). High GCV and PCV values (>20.00\%) were found for number of marketable fruits per plant and marketable fruit yield per plant, indicating the potential of simple selection for the improvement of these characters. These observations find support from the previous workers (Kumar and Arumugam, 2013; Chaudhary and Kumar, 2014) who also found higher magnitudes of GCV and PCV (>20.0\%) for a number of marketable fruits per plant and marketable fruit yield per plant in eggplant. On the other hand, moderate PCV and GCV values (10.00-20.00\%) were shown by plant height, fruit length, fruit girth and average fruit weight. Similar findings had been reported in brinjal for plant height and average fruit weight by Kumar and Arumugam (2013) and for fruit girth by Senapati et al. (2009) who also observed moderate values of PCV and GCV for the said traits. The proportion of GCV to PCV observed in this study was generally high ranged from $90.51 \%$ in plant height to $99.56 \%$ in fruit length and thus, their use as important discriminatory variable for brinjal classification studies seems relatively reliable.

Higher estimates of broad sense heritability (more than $80 \%$ ) coupled with high genetic advance as per cent of mean (more than $20 \%$ ), an indicative of additive gene action, were found for all the characters under study except days to $1^{\text {st }}$ flowering, days to $50 \%$

Table 3. Cluster classification of twenty-seven genotypes of brinjal.

\begin{tabular}{ll}
\hline $\begin{array}{l}\text { Cluster with number of } \\
\text { genotype in parentheses }\end{array}$ & Name of the genotype \\
\hline I (8) & 12/SPT-BR Var-2, 10/BRR Var-3, 10/BRR Var-4, 10/BRR Var-5, 10/BRR Var-6, 10/BRR Var- \\
& 7, Swarna Mani, BCB-10 \\
II (4) & KS-224, Gujrat Brinjal Round, 12/SPT-BR Var-6, 12/SPT-BR Var-8 \\
III (2) & 10 BRR Var-2, 12/SPT-BR Var-5 \\
IV (2) & Punjab Brinjal Round, Gujrat SRP Round \\
V (2) & 12/SPT-BR Var-1, 12/SPT-BR Var-7 \\
VI (3) & Deshi Makra, 12/SPT-BR Var-9, 12/BRBW Res-7 \\
VII (2) & IIVR Purple Round, BCB-30 \\
VIII (2) & 09/BRBW Res-3, 12/SPT-BR Var-3 \\
IX(2) & 12/SPT-BR Var-4, 12/SPT-BR Var-10 \\
\hline
\end{tabular}

Table 4. Inter- and Intra-cluster distances of twenty-seven genotypes of brinjal.

\begin{tabular}{|c|c|c|c|c|c|c|c|c|c|}
\hline$\overline{\text { Cluster }}$ & I & II & III & IV & $\mathbf{V}$ & VI & VII & VIII & IX \\
\hline $\bar{I}$ & 673.74 & 1732.13 & 1343.58 & 1603.73 & 572.27 & 3364.91 & 1220.50 & 1388.44 & 2945.23 \\
\hline II & & 1729.90 & 875.26 & 1012.59 & 956.98 & 2034.50 & 2429.13 & 2690.78 & 1570.35 \\
\hline III & & & 151.17 & 327.44 & 657.82 & 1387.96 & 1427.84 & 2986.49 & 848.30 \\
\hline IV & & & & 204.22 & 808.17 & 1950.93 & 1923.44 & 2991.44 & 1117.22 \\
\hline V & & & & & 232.68 & 2324.79 & 1528.57 & 1242.07 & 1815.65 \\
\hline VI & & & & & & 2096.45 & 3508.11 & 4786.74 & 1423.43 \\
\hline VII & & & & & & & 423.76 & 3018.65 & 3152.87 \\
\hline VIII & & & & & & & & 1572.72 & 4479.41 \\
\hline IX & & & & & & & & & 2030.21 \\
\hline
\end{tabular}


Table 5. Cluster means of nine characters of brinjal.

\begin{tabular}{|c|c|c|c|c|c|c|c|c|c|c|}
\hline \multirow[t]{2}{*}{ Characters } & \multicolumn{9}{|c|}{ Cluster } & \multirow{2}{*}{$\begin{array}{c}\text { (\%) contri- } \\
\text { bution } \\
\text { towards } \\
\text { divergence }\end{array}$} \\
\hline & 1 & 2 & 3 & 4 & 5 & 6 & 7 & 8 & 9 & \\
\hline Days to 1 st flowering & 48.13 & 51.42 & 47.33 & 61.00 & 46.33 & 49.78 & 44.17 & 49.17 & 48.17 & 0.00 \\
\hline Days to $50 \%$ flowering & 58.42 & 65.67 & 62.17 & 75.67 & 61.33 & 66.67 & 53.67 & 66.33 & 67.33 & 0.00 \\
\hline Plant height $(\mathrm{cm})$ & 96.31 & 86.75 & 82.17 & 93.08 & 86.92 & 89.78 & 102.33 & 103.08 & 81.00 & 9.69 \\
\hline Fruit length $(\mathrm{cm})$ & 10.65 & 9.03 & 8.83 & 9.21 & 9.85 & 8.15 & 10.10 & 11.15 & 7.95 & 30.48 \\
\hline Fruit girth $(\mathrm{cm})$ & 8.07 & 6.86 & 7.58 & 8.11 & 7.12 & 6.56 & 9.35 & 7.02 & 6.63 & 20.23 \\
\hline $\begin{array}{l}\text { Average fruit weight } \\
(\mathrm{g})\end{array}$ & 216.96 & 191.08 & $\begin{array}{c}214.1 \\
7\end{array}$ & $\begin{array}{c}196.8 \\
3\end{array}$ & 208.83 & 188.67 & 171.50 & 157.50 & 192.00 & 8.83 \\
\hline $\begin{array}{l}\text { Number of marketable } \\
\text { fruits/plant }\end{array}$ & 5.38 & 6.17 & 5.33 & 4.67 & 5.17 & 8.44 & 8.00 & 7.83 & 6.50 & 1.42 \\
\hline $\begin{array}{l}\text { Marketable fruit yield / } \\
\text { plant }(\mathrm{kg})\end{array}$ & 1.17 & 1.16 & 1.14 & 0.91 & 1.07 & 1.63 & 1.37 & 1.18 & 1.25 & 29.34 \\
\hline
\end{tabular}

Table 6. Results of principal component analysis (PCA).

\begin{tabular}{lllll}
\hline Characters & Vector I & Vector II & Vector III & Vector IV \\
\hline Roots/ Eigen values & 2.141 & 1.858 & 1.587 & 1.157 \\
\% of total variation accounted for & 26.758 & 23.226 & 19.832 & 14.467 \\
\% of cumulative variation & 26.758 & 49.985 & 69.817 & 84.284 \\
Days to 1st flowering & -0.191 & -0.172 & 0.506 & 0.137 \\
Days to 50\% flowering & -0.342 & -0.121 & 0.366 & -0.012 \\
Plant height (cm) & 0.274 & -0.02 & 0.196 & -0.191 \\
Fruit length (cm) & 0.277 & 0.109 & 0.291 & -0.283 \\
Fruit girth (cm) & 0.318 & 0.064 & 0.319 & 0.047 \\
Average fruit weight (g) & 0.204 & -0.186 & 0.005 & 0.702 \\
Number of marketable fruits/plant & -0.136 & 0.505 & 0.091 & -0.06 \\
Marketable fruit yield /plant (kg) & -0.029 & 0.433 & 0.088 & 0.479 \\
\hline
\end{tabular}

flowering and plant height (Table 1). Such observations in brinjal find support from earlier workers (Chaudhary and Kumar, 2014).

Character association: Among the seven yield component traits, significant correlations with marketable yield per plant were shown by number of marketable fruits per plant. However, average fruit weight and number of marketable fruits per plant showed highly positive direct effects on marketable fruit yield per plant (Table 2). In this situation, the direct selection based on these two characters could be beneficial for yield improvement of round fruited brinjal. The results are in conformity with the observations of Lakshmi Rajya et al. (2014) in brinjal. The residual effect was low (0.052) suggesting inclusion of maximum fruit yield influencing characters of round fruited brinjal in the present analysis.

Based on the determination of divergence, all the twenty seven genotypes could meaningfully be grouped into nine clusters (Table 3 ). In general, the pattern of distribution of genotypes from diverse geographical region into different clusters was random. It might be due to free and frequent exchange of genetic materials among the farmers and breeders of different regions. Differential selection pressure according to regional preference also produced greater uniformity in the germplasm.

Genetic diversity of the genotypes through multivariate analysis: The minimum inter-cluster distance was observed between Cluster III and IV (327.44) indicating close relationship among the genotypes belonging to these clusters while, the maximum intercluster value was observed between Cluster VI and VIII (4786.74) followed by 4479.41 between Cluster VIII and IX which indicated that the genotypes included in these clusters had the maximum divergence. Hence, intermating between the genotypes included in these clusters could be expected to give transgressive segregates in the advanced generation as suggested by Kalloo et al. (1980). The minimum intra-cluster distance among genotypes was observed in Cluster III (151.17) and the maximum being in cluster VI (2096.45) followed by 2030.21 in Cluster IX (Table 4). Number of marketable fruits per plant and fruit length contributed most towards genetic divergence (Table 5). In further study of dendrogram following Ward's method (Fig. 1) by using squared Euclidean distance, it became clearly evident that there was high diversity among the genotypes along with strong relationships among the genotypes.

PCA analysis: The principal component analysis (PCA) revealed that 4 components among 8 having eigen values greater than one have contributed 84.28 $\%$ of the variability among the genotypes (Table 6). The first principal component has high positive component loading from plant height contributing maximum to the total genetic variability. From the second principal component number of marketable fruits/plant 
contributed maximum to the total genetic variability. Days to first flowering and fruit girth recorded highest component loading from third component contributing maximum to the total genetic variability from this component. Average fruit weight and marketable fruit yield per plant contributed maximum for variability from fourth principal component. Similar studies on variability in brinjal using PCA have also been done by previous workers (Begum et al., 2013, Solaiman et al., 2014) who also observed that the clustering pattern obtained coincided with the apparent grouping patterns performed by PCA.

Based on genetic divergence and scattered diagram (Fig. 2) through principal component analysis, six genotypes (BCB-30, Deshi Makra, Gujrat Brinjal Round, 09/BRBWRES-3, BCB-10, 10/BRRVar-2) possessed the optimum combination of all variables and should be considered for use in further breeding programme to develop improved lines for export purpose.

\section{Conclusion}

From the yield component analysis, it can be concluded that emphasis should be given on number of marketable fruits per plant and average fruit weight which exhibited positive correlations $\left(\mathrm{r}=0.725^{*}\right.$ and $\mathrm{r}=$ 0.143 , respectively) and higher magnitudes of direct effects (1.242 and 0.834 , respectively) on marketable fruit yield per plant for selecting high yielding genotypes of round fruited brinjal. Based on the degree of divergence, the genotypes were grouped into nine clusters. Crossing between genotypes belonging to Cluster VI and VIII having the maximum inter-cluster value (4786.74) could produce highly productive brinjal genotypes. Based on averages and principal component analysis, six genotypes (BCB-30, Deshi Makra, Gujrat Brinjal Round, 09/BRBWRes-3, BCB-10, 10/BRRVar -2) could be utilized further in export oriented breeding programs.

\section{REFERENCES}

Begum, F, Aminul Islam, A.K.M., Golam Rasul, M., Khaleque Mian, M.A. and Mofazzal Hossain, M. (2013). Morphological diversity of eggplant (Solanum melongena) in Bangladesh. Emirates Journal of Food and Agriculture, 25(1): 45-51.

Cericola, F., Portis, E., Toppino, L., Barchi, L., Acciarri, N., Ciriaci, T., Sala, T., Rotino, G.L. and Lanteri, S. (2013). The population structure and diversity of eggplant from Asia and the Mediterranean basin. PloS One, 8 (9):e73702.

Chattopadhyay, A., Dutta, S., Bhattacharya, I., Karmakar, K. and Hazra, P. (2007). Technology for vegetable crop production, published by All India Coordinated Research Project on vegetable crops, Directorate of Research, Bidhan Chandra Krishi Viswavidyalaya,
Kalyani-741235, Nadia, West Bengal, INDIA pp. 226. Chattopadhyay, Arup, Dutta, Subrata and Hazra, Pranab (2011). Characterization of genetic resources and identification of selection indices of brinjal (Solanum melongena L.) grown in eastern India. Vegetable Crops Research Bulletin, 74: 39-49.

Chaudhary, P. and Kumar, S. (2014). Variability, heritability and genetic advance studies in egg-plant (Solanun melongena L.). Plant Archives, 14(1): 483-486.

Dewey, D. R. and Lu, H. K. (1959). A correlation and pathcoefficient analysis of components of crested wheat grass production. Agronomy Journal, 51: 515-518.

Hanson, C. H., Robinson, H. F. and Comstock, R. E. (1956). Biometrical studies of yield in segregating population of Korean lespedza. Agronomy Journal, 48: 268-272.

Hazra, P., Rout, A., Roy, U., Nath, S., Roy, T., Dutta, R., Acharya, S. and Mondal, A. K. (2003). Characterization of brinjal (Solanum melongena L.) germplasm. Vegetable Science, 30: 145-149.

Johnson, H.W., Rabinson, H.F. and Comstock, R.E. (1955). Genotypic and phenotypic correlation in soybean and their implication in selection. Agronomy Journal, 47: 477-483.

Kalloo, G., Singh, V. P., Dudi, B.S. and Partap, P.S. (1980). Analysis of variation and genetic divergence in garden peas (Pisum sativum L.). Haryana Agricultural University Journal of Research, 10: 540-546.

Kumar, S.R. and Arumugam, T. (2013). Variability, heritability and genetic advance for fruit yield, quality and pest and disease incidence in eggplant. Vegetable Science, 40 (1): 111-113.

Lakshmi Rajya, R., Vijaya Padma, S. S., Naram Naidu, L. and Umajyothi, K. (2014). Correlation and path analysis studies of yield and yield components in brinjal. Plant Archives, 14(1): 583-591.

Mahalanobis, P. C. (1936). On the generalized distance in statistics. Proceedings of the National Institute of Science (India), 12: 49-55.

Rao, C. R. (1952). Adavance Statistical Methods in Biometrics. John Willey and Sons Inc., New York.

Senapati, N., Mishra, H. N., Bhoi, M. K., Dash, S. K. and Prasad, G. (2009). Genetic variability and divergence studies in brinjal (Solanum melongena L.). Vegetable Science, 36(2): 150-154

Sidhu, A. S., Bal, S. S., Behera, T. K. and Rani, M. (2005). An outlook in hybrid eggplant breeding. Journal of New Seeds, 6(2-3):15-29.

Singh, K. and Pandey, U. B. (1993). Export of vegetablesstatus and strategies. Vegetable Science, 20:93-103

Solaiman, A. H.M., Nishizawa T., Khatun, M. and Ahmad, S. (2014). Morphological characterization and genetic diversity studies of promising brinjal genotypes for hybridization program in Bangladesh. Jounal of $A d$ vances in Agriculture, 3(3): 218-228.

Vanitha, S.M., Chaurasia, S.N.S., Singh, P.M. and Naik, P. S. (2013). Vegetable statistics. Technical Bulletin No. 51, IIVR, Varanasi P. 250.

Ward, J.H. (1963). Hierarchical grouping to optimize an objective function. Jounal of the American Statistical Association, 58: 236-244. 